\title{
Chapter 7 \\ Development of tourism and second homes in the area of Sviščaki in southwestern Slovenia
}

\author{
Gregor Kovačič, Miha Koderman
}

\section{Abstract}

The hamlet Sviščaki is located in the Municipality of Ilirska Bistrica and is one of the largest mountainous second home areas in southwestern Slovenia. It lies in the close vicinity of Veliki Snežnik Mountain (1,796 $\mathrm{m}$ a.s.l.), the highest mountain in southern Slovenia. In this chapter, we present the development of Sviščaki in the context of the tourism development on Snežnik Plateau. We analyse the current condition of tourist infrastructure, while focusing on spatial analysis of second homes and other communal and tourism infrastructure in Sviščaki. We also evaluate future perspectives for the tourism development of Sviščaki according to the Municipal Detailed Spatial Plan for the Sviščaki Tourist Centre. Spatial analysis of second homes was carried out with the help of the Real Estate Registry and the Public Insight into Real Estate website, which is managed by the Surveying and Mapping Authority of the Republic of Slovenia. The evaluation of the future development of the area as a tourist centre was based on professional documents related to the process of implementation of the aforementioned spatial plan for the Sviščaki Tourist Centre.

Key words: second homes, tourism development, protected area, geography, Sviščaki, Snežnik, Ilirska Bistrica, Slovenia 


\section{Introduction}

The hamlet Sviščaki is located in the Municipality of Ilirska Bistrica and represents one of the largest second home settlements in the region of Notranjska (Gosar, 1987, 258), as well as in southwestern Slovenia. Sviščaki is not an independent settlement, rather it is integrated into the settlement Snežnik, which extends over $95 \mathrm{~km}^{2}$, together with the hamlets Gomanci and Mašun, as well as individual cottages on Snežnik Plateau that belong to foresters, hunters, or vacationers. In the wider area of Snežnik Plateau, there are also other second home settlements, for example in Rakov Škocjan, Gorenje Jezero, and Leskova Dolina.

Snežnik Plateau is a high and forested karst plateau located in the south of Slovenia; it is most often discussed together with the neighbouring and somewhat lower area of Javorniki. Considering the altitude and the topographical features of land relief, the best name that has emerged for the unified area of Snežnik and Javorniki is Snežnik-Javorniki Plateau (Snežniško-javorniška planota). Geographers tend to use various names for this area. Klemenčič (1959), Melik (1960), Lovrenčak (1976) and Gams (1986) called it the Snežnik-Javorniki Mountain Range (Snežniš̌ko-javorniš̌ko pogorje) or Mountains (gorovje), while Lovrenčak (1976) also used the names Snežnik Mountain Range (Snežniško pogorje) and Snežnik-Javorniki Plateau (Snežniško-javorniška planota). Melik (1960) named the whole area Snežnik; Gams (1983), Perko and Orožen Adamič (1998) as well as Senegačnik (2012) called it Javorniki and Snežnik, while Gams, Kladnik, and Orožen Adamič (1995) also used the names Snežnik and Javorniki.

These different names indicate the evident existence of two orographic toponyms, where Javorniki occupies the northern part of the region, while Snežnik Plateau or Snežnik extends to the south (Zupančič, 1998, 334). The borderline separating them runs through dry valleys and larger karst depressions between Knežak, Mašun, Leskova Dolina, and Loško Polje. In the northeast, Snežnik Plateau is delimited by Cerknica Polje and Lož Polje, while in the west and southwest, it descends across steep slopes into the valley of the Reka River, and continues into the large wooded area of Gorski Kotar in Croatia further to the south (Kovačič, 2001; 2003). The core of Snežnik Plateau, where we find the Sviščaki second home settlement, is a high area ranging from 1,200 to $1,796 \mathrm{~m}$ a.s.l., which is the altitude of the Plateau's highest peak: Veliki Snežnik (Klemenčič, 1959). The total area of the predominantly wooded and mostly uninhabited Snežnik-Javorniki Plateau is $458 \mathrm{~km}^{2}$ (Zupančič, 1998, 334). 
The area is known for extensive forests and represents an important protected area, which is included in the Natura 2000 directive. Since 2017, part of the extensive forest complex in this protected area has been part of the transnational UNESCO World Heritage List, under the category of Ancient and Primeval Beech Forests of the Carpathians and Other Regions of Europe (UNESCO, 2019).

The aim of this paper is to present the development of the second home settlement Sviščaki in the context of tourism development on the Snežnik Plateau by analysing the current state and establishment of the tourist centre with a focus on spatial analysis of the holiday dwellings, other community infrastructure and tourist facilities in Sviščaki, and evaluating plans for the future tourist development of Sviščaki in the framework of the Municipal Detailed Spatial Plan for the Tourist Centre Sviščaki (hereinafter OPPN Sviščaki) (Development Center Planiranje, 2018a; 2018b; Romih et al. 2018; Official Gazette of the Republic of Slovenia 62, 2019).

The spatial analysis of the holiday dwellings was performed with the help of the Real Estate Registry and the Public Insight into Real Estate portal, managed by the Surveying and Mapping Authority of the Republic of Slovenia. Assessment of the tourist centre's future development possibilities was carried out on the basis of technical documents related to the procedure of approval of the OPPN Sviščaki (Development Center Planiranje, 2018a; 2018b; Romih et al., 2018) and the Ordinance on the Municipal Detailed Spatial Plan for the Sviščaki Tourist Centre (Official Gazette of the Republic of Slovenia 62, 2019).

\section{Development of tourism in the wider area of Sviščaki}

The development of tourism in the wider area of Sviščaki can be divided into two periods.

\section{Development in the interwar period}

The beginning of tourism in Sviščaki is associated with the period after World War I, when the Snežnik-Javorniki Plateau fell under the control of the Kingdom of Italy almost in its entirety. The Italian government extensively supported the construction of mountain huts in the Snežnik area due to the vicinity of border with the Kingdom of Serbs, Croats, and Slovenes (later the Kingdom of Yugoslavia), in addition to encouraging the construction of military and semi-military facilities and 
connecting roads (Čeligoj, 2019a). These mountain huts were built by the Italian Alpine Club (CAI-Club Alpino Italiano). In September of 1925, the Rijeka section of the CAI built the largest mountain hut in the east of the Kingdom of Italy in Sviščaki; the hut was named Rifugio Gabriele d'Annunzio, $1242 m$ (Čeligoj, 200oa). Veliki Snežnik was becoming an ever more popular day trip destination attracting numerous locals and other visitors, and from that moment on Sviščaki became the central starting point for ascending the peak.

In Ilirska Bistrica, the local branch of the Alpine Association of Slovenia (established in 1907) was still active at the time, but Italian authorities attempted to hinder its activities and pressured mountaineers to join the Rijeka chapter of the CAI (Čeligoj, 20oob). In 1926, the mountaineering subsection of the Rijeka-based CAI was founded in Ilirska Bistrica, which the locals, however, tended to ignore for the most part (Čeligoj, 200oa). The mountain hut in Sviščaki was not the first hut in the area of Snežnik, and the ruins of the first hut are still visible at the time of writing. It was built by the Littoral Branch of the Trieste German and Austrian Alpine Club (Wraber, 200o) on the eastern side of Veliki Snežnik in 1874. In 1914, mountaineers from Bistrica built the hut Vilharjeva koča $v$ Crnem dolu on the ruins of the old cottage a little west of Sviščaki, in the frost pocket of Črni Dol; the hut was, however, forcibly confiscated by Italian authorities in 1927 and handed over to the Rijeka chapter of the CAI (Čeligoj, 20oob).

Some other mountain huts were constructed in the interwar period in the area of Snežnik which no longer exist today, for example the shelter Capanna Angheben and the mountain hut Rifugio Guido Rey on Klanska Polica, which was organised and run like a hotel (Čeligoj, 2019a; 2019b). In order to provide a supply of drinking water on a limestone karst plateau without any available sources of surface water, reservoirs for drainage water were also built, in addition to military and civilian outposts; there are two such reservoirs in Sviščaki. Sviščaki, Klanska Polica (with three supplied huts) and Črni Dol also turned into the "skiing centres" on Snežnik Plateau over time (Čeligoj, 2019c); skiing competitions were organised there occasionally in the past, including competitions in ski jumping (Čeligoj, 2019C; 2019d; 2019e). In this era, the majority of skiers were inhabitants of Rijeka, who usually travelled to Ilirska Bistrica by train and then took lorries to reach the outposts (Čeligoj, 2019c). 


\section{Post-war restoration of mountaineering and the renovation of mountain huts}

Only the hut Vilharjeva koča in Črni dol survived World War II intact, while other mountain huts were demolished; nothing but the walls remained of the burnt-down hut in Sviščaki. The mountaineers of Ilirska Bistrica restructured the commercial premises of the former mountain hut Rifugio Gabriele d'Annunzio, 1242 m, in the period between 1948 and 1951, into a new humble hut named Cankarjeva koča $1242 \mathrm{~m}$ pod Snežnikom. In the 1950s, the hut was left deserted, which was the result of vandalism-people who were not from the area were regularly breaking in and stealing supplies (Čeligoj, 200oc).

At the end of the 1950 and the beginning of the 196os, Sviščaki became increasingly interesting regarding the prospects of tourism and recreation, as snow-rich winters inspired people to take part in winter sports. This provided the impetus for the construction of the first holiday homes in 1963, undertaken by different companies from Ilirska Bistrica (more on this in chapter Development of the second homes in Sviščaki), while, simultaneously, construction works were started for a new mountain hut in Sviščaki: Planinski dom na Sviščakih, which was publicly opened in 1968 (Čeligoj, 2oood). Later, the mountain hut was renovated several times; for the last time, to a greater extent, in 1983, when plumbing fixtures as well as electricity and sanitary fittings were added in an extension, and in 1993, when a mobile phone connection became available (Mountain Hut Sviščaki, 2019; Alpine Association of Slovenia, 2019a).

An important milestone in the development of mountaineering in the area of Snežnik was the construction of a mountain hut on Veliki Snežnik, which was built upon the ruins of a former Italian anti-aircraft lookout post. The construction started in 1958 and was finished in 1961, after the shelter Zavetišče na Velikem Snežniku 1796 m was officially closed down (Čeligoj, 20ooe). In the years that followed, the shelter was extended with additional premises and, in 1977, it was significantly expanded and renovated; in the 1990s, the water supply installations and a telephone connection were also added. At the end of the 199os, the shelter was renamed to Koča Draga Karolina na Velikem Snežniku (179o m) (Čeligoj, 20oof). The cottage offers 20 shared beds and 8 beds in individual rooms, as well as 80 seats in the dining hall (Alpine Association of Slovenia, 2019b). In 2007, the kitchen was renovated, a retaining wall was built, the well and chimney were reconstructed, a protective fence was put up around the shelter, and the win- 
dows and most doors were replaced; in 2009, a more efficient solar power station was constructed and electrical installations in the cottage were renovated (Jaksetič, 2009).

The beginning of the 1990s also brought important political and socio-economic changes with the disintegration of the Socialist Federal Republic of Yugoslavia. A new international border was established between the former Yugoslav federal republics of Slovenia and Croatia and free mobility of mountaineers and hikers across the newly established border was now formally limited to the border crossings that were set on the main roads connecting the two countries.

\section{Development of skiing in Sviščaki}

The wider area of Sviščaki does not only have a long tradition as a popular hiking resort (especially from spring to autumn); since the second half of the 1960s, Sviščaki has been a significant area in terms of winter sports and recreation. The development of "contemporary" organised skiing in Sviščaki began in 1967 when a skiing division was established in the local Alpine Association, and only a year later the unaffiliated Skiing Club Snežnik was founded (Ski Club Snežnik, 2019a), which started constructing ski runs in Sviščaki. In 1968 and 1969, the first ski run was built by involving volunteers and the military, and a motorised ski lift was acquired (Ski Club Snežnik, 2019c).

The year 1969 witnessed the organisation of the first ski course with 120 participants (Ski Club Snežnik, 2019b), while the first competitions and courses for skiing instructors followed in the next few years. In the 19711984 period, the so-called "Snežnik Cup" was organised annually at the end of the skiing season in May-a spectacular skiing competition starting from the very top of Snežnik (Ski Club Snežnik, 2019d). In 1972, a more efficient electrically-operated stand-alone ski lift was introduced, after electricity was brought to Sviščaki (Ski Club Snežnik, 2019c). Simultaneously, a smaller ski hut was built by the side of the ski slope and the first snow machines were acquired. The development of demand for skiing in Sviščaki quickly exceeded what the club could offer, which is why the management and organisation of the ski centre were taken over by the Municipality of Ilirska Bistrica (Ski Club, 2019c).

In 1985, a less steep ski run was created beside the main one, and two more ski runs as well as another ski lift were also added. The latter turned out to be unprofitable, as the ski run happened to be situated on the sunny 
side of the mountain. This sealed the complete image of the skiing centre with four ski runs, a total length of 1.5 kilometres and the surface of 5.7 hectares (Slovenian Forest Service, 2013) as well as two ski lifts with a capacity of up to 1,330 skiers per hour (Vesenjak, 2010).

\section{Condition of the mountaineering facilities and other tourist infrastructure in Sviščaki}

As of the middle of 2019, the restaurant of the mountain hut in Sviščaki seats 38 , while the tables in front of the building seat from 80 to 100 people, and the dormitory offers 11 shared beds. There is also free parking available in front. Toilet facilities and a washroom with cold water are available in the extension; the restaurant and dormitory rooms are heated via central heating (Alpine Association of Slovenia, 2019a). The hut as a whole is heated by wood-burning stoves, and potable water is supplied from the hut's own drainage water reservoir (200 $\mathrm{m}^{3}$ volume), which had been built to supply the shelter Rifugio Gabriele d'Annunzio, $1242 \mathrm{~m}$ (Fig. 1). Before entering the system, water is further purified using filtration and UV disinfection.

The mountain hut only records roughly 50 overnight stays per year, which indicates a lack of demand for this kind of vacation accomodation (Čosić, 2019). While this may also be partly the result of inappropriately furnished accommodation facilities, which are currently suitable only for an overnight stay and do not offer many comforts for those who might wish to stay longer than a single night. The majority of overnight guests come here in the summer months (especially in August) and in winter, when the frequency of visits depends heavily on weather conditions (i.e. if conditions allow for sledding). On average, the hut hosts approximately 10,000 visitors annually (Čosić, 2019); the lower number of visits in the winter months in the last few years is related to the fact that the ski facilities have been out of service since 2014 (Kalc Furlanič, 2015).

Due to several successive snow-light winters and the unwillingness of the municipality to invest large resources into the deteriorating ski lift machinery, which is no longer safe and should be fully replaced and renovated, the municipality has not posted any public calls for firms interested in gaining the concession to manage the ski resort since 2015 (Kalc Furlanič, 2015). Before 2014, the ski runs operated only two weeks, on average, and without artificial snow it was impossible to achieve commercial viability. Artificial production of snow, with which the skiing season could be prolonged, is associated with considerable investment pertaining to the con- 


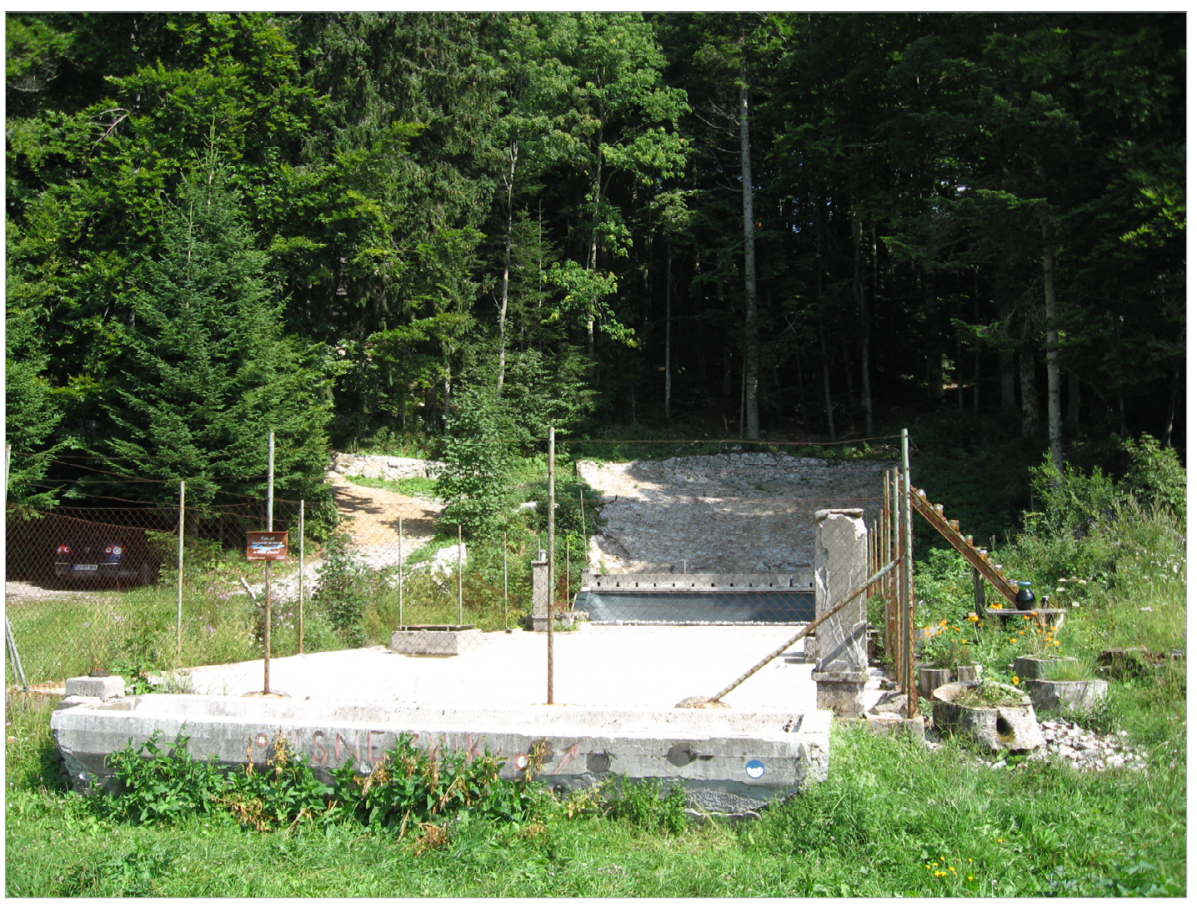

Fig. I A drainage water reservoir, built in the period of Italian occupation Photo by Gregor Kovačič, 2019

struction of basins for retaining precipitation water and snowmaking facilities (Francek Ivović, 2015). Furthermore, the existing skiing facilities and infrastructure are deteriorating, and the ski runs are becoming overgrown by shrubs.

These facts shed some doubt on whether it makes any sense to attempt to re-establish or further develop skiing tourism in Sviščaki, especially considering the trend of increasing air temperatures due to global warming. Regarding winter forms of outdoor recreation, sledding, recreational cross-country skiing, and hiking seem like more realistic options. Hikers can follow numerous forest trails in the vicinity of Sviščaki and across Snežnik Plateau.

In 2019, the mountain hut was in the process of renovation. The investment of around $€ 120$,ooo consisted of a non-refundable European grant for energy-saving building renovations in the amount of $€ 63,000$, added to the owner's own contribution (the owner is the Snežnik Alpine Club, based in Ilirska Bistrica). The hut will be raised by a meter and rooms with sever- 
al beds will be furnished, while the outside image of the hut will stay the same. The hut will offer 19 beds in four rooms with proper sanitary facilities (Francek Ivović, 2018b; Kirn Vodopivec, 2019a; 2019b).

The visitors can park their vehicles in the car park on the eastern side of Sviščaki. The reconstruction of an approximately seven-kilometre section of the nearby state road (completed in November 2019) included the reconstruction of embankments and retaining walls, the implementation of loading ramps for felled timber, and the installation of steel protective rails (Kirn Vodopivec, 2019a).

\section{Development of the second homes in Sviščaki}

The construction of the mountain hut and the development of skiing gave rise to the popularity of Sviščaki, which gave rise to new possibilities for the development of a smaller tourism and recreational centre. With the assent of the Municipality of Ilirska Bistrica, the first holiday huts were built by the local companies Lesonit, Topol, Transport, Ilirija, etc. in the 1960s and were intended for the companies' employees to use for vacation (even before the new mountain hut was finished), although Sviščaki were still without electricity at the time (Čeligoj, 20ood). In 1967, the Municipality of Ilirska Bistrica passed The Ordinance of the Development Plan for the Area of Sviščaki (1967) and The Rules on the Implementation of the Development Plan for the Area of Sviščaki (1967), and thus defined the Sviščaki area as a construction land zone, intended for the construction of second homes, which accelerated the building of houses.

The holiday settlement Sviščaki (an agglomeration of second home dwellings) spreads over an area of approximately 8 hectares (Slovenian Forest Service, 2013). The first houses were built at the edge of a clearing by the mountain hut on Veliki Sviščaki (Fig. 2). The construction of houses soon spread from the forest clearing towards the gravel road that runs to Mali Sviščaki-where we find most new construction. These are located somewhat higher, above the bottom of the shallow doline, with temperature inversion typically occurring in the colder part of the year. There is an $18.5 \mathrm{~km}$ state road leading from the largest centre in the vicinity, Ilirska Bistrica, to Sviščaki. In the last decade, the number of inhabitants in the settlement of Snežnik, of which Sviščaki is a part, varied between 17 and 25 . There were 19 people living permanently in the settlement in 2019, 10 of which were male (Statistical Office of the Republic of Slovenia, 2019). 


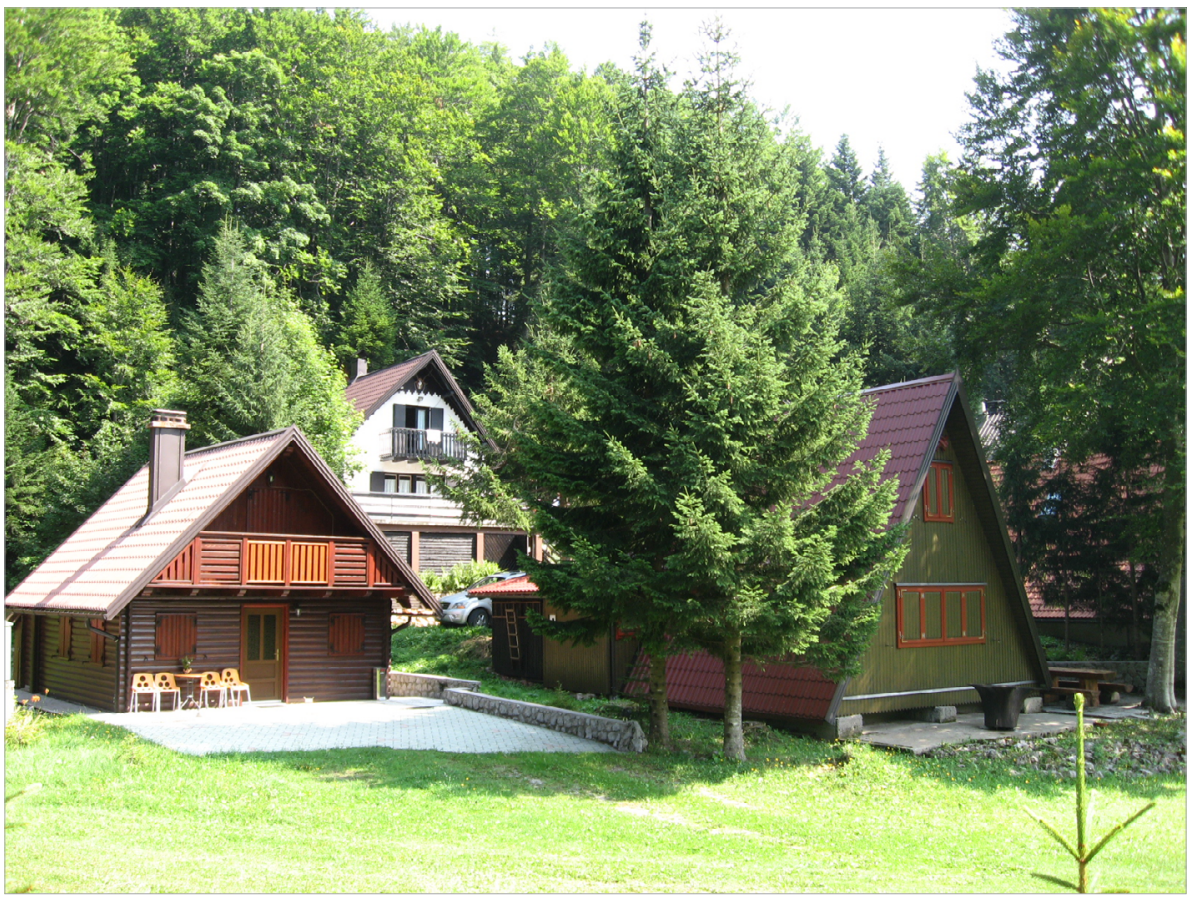

Fig 2. Second homes in Sviščaki

Photo by Gregor Kovačič, 2019

The owners of the second homes are merely tenants on the land upon which their buildings stand. The owner of the majority of the woods in Sviščaki (Slovenian Forest Service, 2013), and the six forested parcels where these dwellings are located, is the Municipality of Ilirska Bistrica, with whom the owners entered into long-term leases with a maturity of up to 99 years (Ferko, 2013). In Sviščaki, no zoning has ever been made that would allow each building to occupy its own (privately-owned) parcel of land. Locations of holiday cabins are sequentially numbered in the order in which they had been built, and parcels were leased in the same order (Ferko, 2013).

With new tenants or those whose contracts have expired, the municipality enters into contracts with a five-year maturity (Municipality of Ilirska Bistrica, 2019). The municipality charges 128 euros annually for the lease of a land parcel, regardless of its size (Ferko, 2013). The ownership structure of the holiday establishments shows that in 2016, there were 13 legal entities registered as tenants, while the rest of the tenants were natural 
persons. Of the latter, 23 lived in the municipality of Ilirska Bistrica and 58 came from other Slovenian municipalities. In 2016, the tenants also included 6 Italian citizens and 2 Croatian citizens (Brižan, 2016).

The occupancy of the holiday houses in Sviščaki is low and they are empty much of the year (Francek Ivović, 2017; 2018a; Mulec, 2018) - around 20 of them seem to be in permanent use, while some are even deteriorating (Čošić, 2019). The manager of the mountain hut and some of the owners of the holiday houses in Sviščaki believe that there is demand for accommodation in the holiday huts, but not many have been offered for this purpose on the market (Francek Ivović, 2017; Čosić, 2019). On Booking.com (the most famous online accommodation provider) we find only one person offering to rent out a holiday home in Sviščaki. The majority of the cabins' owners perceive their property as a family heirloom that they do not wish to share with others.

Nonetheless, some people like the idea of offering their holiday hut for vacationers to rent while they aren't using it. They are partly forced to consider this option because of the high costs of maintaining the facilities and renovation in an area where summers are short, while empty houses also decay faster. In 2017, the Tourist Cooperative Sviščaki was established for this purpose, bringing together property owners who would like to rent their holiday houses to tourists. Accommodation would be offered under the name of the Dispersed Hotel Sviščaki. The co-operative would be responsible for the rental of houses, administration, and all operational activities related to rental and the actual accommodation of guests, which would relieve the owners of the burden of such obligations entirely (Francek Ivović, 2017; 2018a; 2018b; Mulec, 2018).

The expansion of the second home settlement was, however, not accompanied by site development services which the municipality should have provided. The owners of the holiday homes thus tackled the provision of utilities for their establishments individually. As a matter of fact, holiday dwellings require quite extensive infrastructure, as one needs to secure a water supply, the disposal of municipal sewage and proper waste disposal, set up electricity, ensure sufficient transport accessibility, as well as the access to mobile telephone services and the internet (Cigale, 2009). Sviščaki got electricity in 1972 when a $20 \mathrm{kV}$ electrical power line was installed, connecting the settlement to Ilirska Bistrica (Slovenian Forest Service, 2013). Two transformer stations were built that meet current power consumption 
(Vesenjak, 2010). The buildings' owners had to co-finance individual electric connections to their holiday homes.

A potable water supply was obtained by most of the houses' owners by constructing reservoirs for harvesting rainwater, either on the roof or beside their holiday huts, while quality drinking water is supplied by various convenient water filtration systems. Some houses are supplied with drinking water from the rainwater reservoir that was constructed in the period of Italian occupation, found at the edge of the clearing (Fig. 1); the owners of the holiday cabins maintain the reservoir without aid from the Municipality. The disposal of waste water is managed through the use of septic tanks. On the basis of the facilities' age and the general assessment of the condition of septic tanks in Slovenia (Tavčar, 2015), we can infer that most septic tanks are still flow-through systems, which can be problematic for the fragile underground waterways that are characteristic for karst landscapes.

There is no land-line telephone network, but mobile telephone service is available. During the heating season, which tends to be very long, most of the holiday houses use wood heating, while some also use fuel oil or electricity for heating. During special weather conditions, solid fuel heating can cause the air pollution in the area of Sviščaki, especially in the clearing where there is occasionally a minor temperature inversion in the shallow doline. The negative impact of air pollution is somewhat mitigated by the holiday houses' location in the forest.

Waste collection is organised in the car park on the weastern side of Sviščaki, where waste is collected separately in large containers in the manner that is uniformly prescribed for the whole region of the Municipality of Ilirska Bistrica (Fig. 3). Strong winds or wild animals will often scatter trash from the containers if they are not properly closed.

\section{Spatial analysis of the holiday dwellings in Sviščaki}

In this research, we analysed data on the buildings of the Sviščaki settlement. As mentioned in the introduction, the data were obtained from the Real Estate Registry of the Surveying and Mapping Authority of the Republic of Slovenia, which has proved to be a useful source of information for geographical research (for example, Komac et al., 2012; Koderman and Salmič, 2013; Salmič and Koderman, 2013; Koderman, 2014; 2017; Koderman and Pavlič, 2019). In order to acquire additional information regarding individual buildings, and numbers on the parcels and proprietorship, we also consulted the Public Insight into Real Estate website, which 


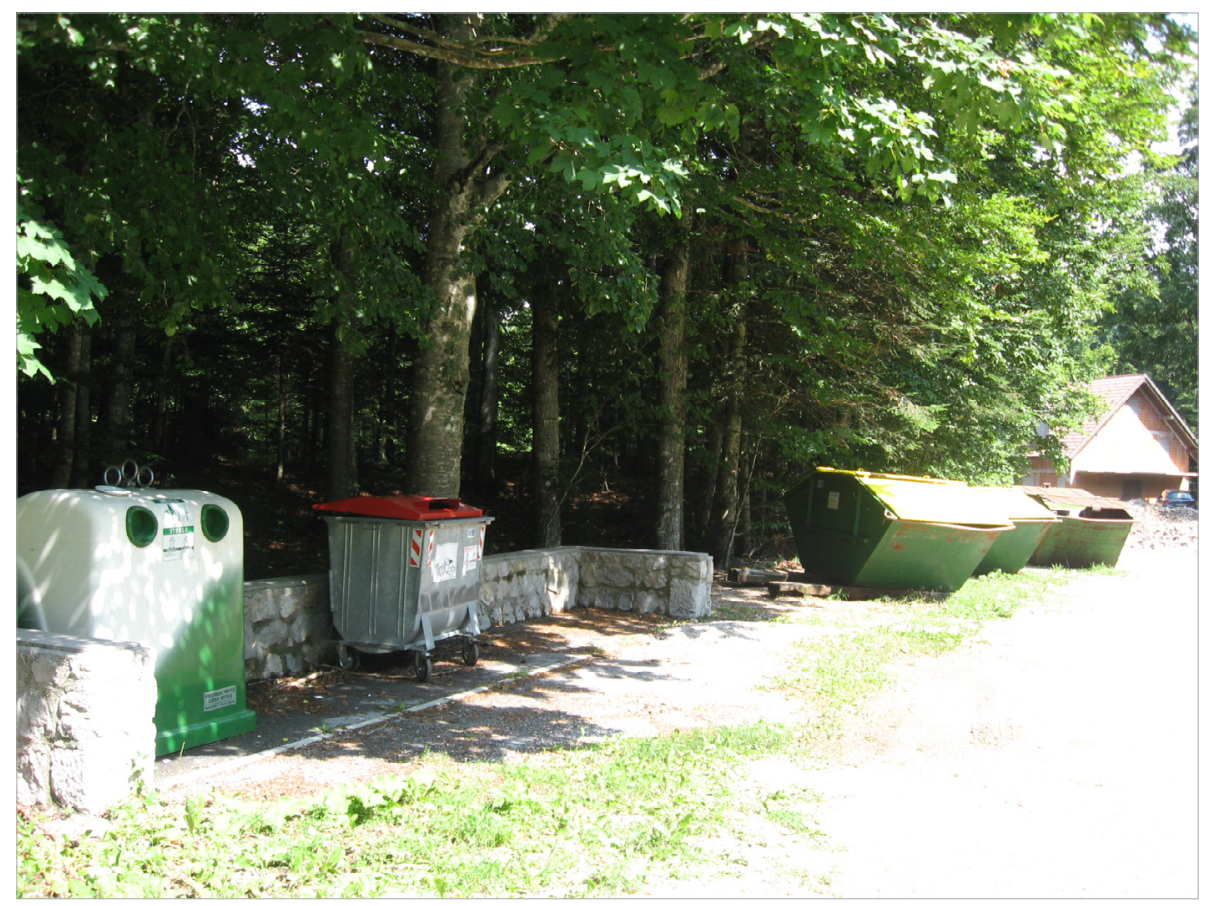

Fig. 3 The waste collection area in Sviščaki

Photo by Gregor Kovačič, 2019

is also managed by the Surveying and Mapping Authority of the Republic of Slovenia.

From the dataset of cadastral municipality 2508, Snežnik, we eliminated all the units which were not located in the area of Veliki and Mali Sviščaki (those with parcel numbers 2049/30, 2049/32, 2055/19, 2055/21, 2058/2, and 2067/14), in the first phase of research. Out of the total of 162 units in the cadastral municipality, we identified 100 buildings as the subjects of further analysis. In the second stage, we eliminated 4 more buildings that were not holiday dwellings: the mountain hut; two commercial establishments recorded as garages in the Real Estate Registry; and the transformer station.

The subject of the detailed spatial analysis was now narrowed to 96 autonomous buildings, i.e. holiday houses. Many of these have accompanying woodsheds, terraces, drainage water reservoirs, improvised car parks, as well as proper access roads. The mountain hut and 12 holiday houses have house numbers, while none of the accompanying facilities are regis- 
tered in the building cadastre. Almost all of the buildings are single dwelling holiday houses, there are only two multi-apartment houses (one has two and the other three apartments) (Surveying and Mapping Authority of the Republic of Slovenia, 2019).

The external design of the holiday houses varies in terms of roof slope and overall design. Some buildings are entirely made of bricks and have a façade, while others are wholly wooden, which gives the impression of a lack of architectural coordination in terms of construction. The reason for this state of things can be found in the very vaguely written Rules on the Implementation of the Construction Plan for the Area of Sviščaki (1967), as well as lack of required know-how or a sense of how construction should be managed in such areas; the situation can also be attributed to the lack of state control. Some investors took advantage of this and constructed buildings outside of the permitted size-instead of small holiday huts, large tourism establishments appeared in some cases (Ferko, 2013; Fig. 4). Individuals, sometimes in cooperation with each other, also arranged ac-

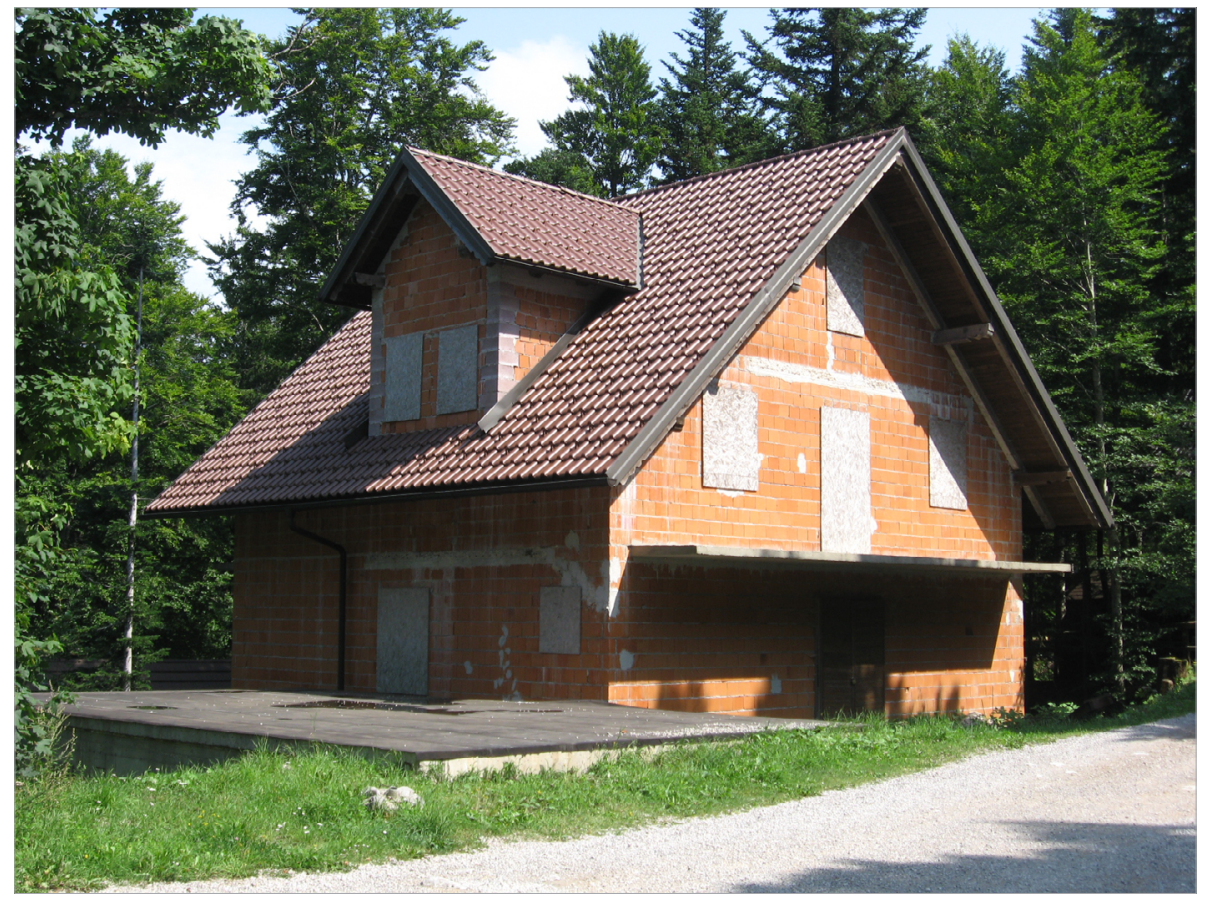

Fig. 4 An example of a holiday house which has remained unfinished for almost a decade Photo by Gregor Kovačič, 2019 
cess to their houses and the outside of the houses according to their needs (parking places, constructed terraces, woodsheds, etc.).

The number of the holiday houses has quickly risen over the decades and, due to inadequate spatial plans, buildings were built without a systematic distribution throughout the area and without architectural uniformity, which has resulted in inefficient use of space; the edges of the settlement are also vaguely defined. Nonetheless, the location of the holiday houses in the forest somewhat mitigates its generally bad image, which is not suitable in terms of urban and architectural planning.

According to data from the Real Estate Registry, the first holiday house was built in 1958 (Fig. 5). In the 1960s, 13 new dwellings appeared on the edges of the clearing beside the mountain hut, and the same number of dwellings was also constructed in the following decade. The average floor area of these buildings ranged between 46.6 and $46.8 \mathrm{~m}^{2}$. In the 1980s, the construction of holiday dwellings spread and flourished; as many as 37 new

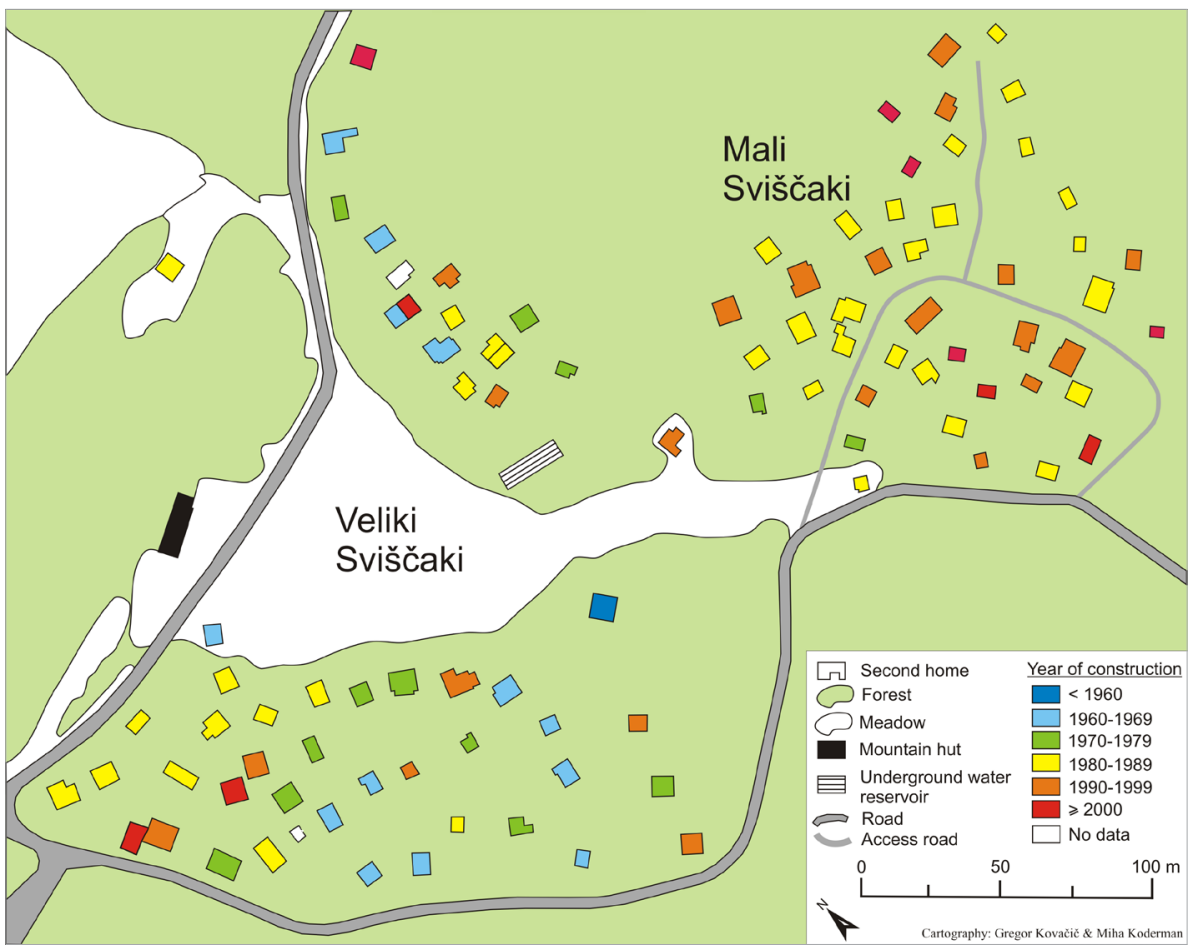

Fig. 5 The age structure of the holiday dwellings in Sviščaki in 2019 Source: Surveying and Mapping Authority of the Republic of Slovenia, 2019 
buildings with an average floor area of $43 \mathrm{~m}^{2}$ were built in the area of Veliki and Mali Sviščaki during this period. In the 1990s, the intensity of construction somewhat dropped, as only 22 new buildings were built, followed by another 10 in the first decade of the $21^{\text {st }}$ century (the most recent was constructed in 2005). The average floor area of the buildings constructed in the $1990 \mathrm{os}$ is $55.5 \mathrm{~m}^{2}$, while the average floor area of those constructed after the year 2000 is a mere $33 \mathrm{~m}^{2}$. We only identified three buildings with a floor area of less than $20 \mathrm{~m}^{2}$ (the smallest buildings measured only 15 or 14.5 $\mathrm{m}^{2}$ ), while the floor area of eight buildings exceeded $90 \mathrm{~m}^{2}$ (the two largest had 111 and $120 \mathrm{~m}^{2}$ of the floor area). The floor area of holiday dwellings is shown in Fig. 6.

What should be added to the data on the buildings' average floor area is the fact that both the Real Estate Registry as well as the Public Insight into Real Estate website revealed that most holiday buildings (57 out of 96 buildings - there was no information on 9 buildings) have at least two or

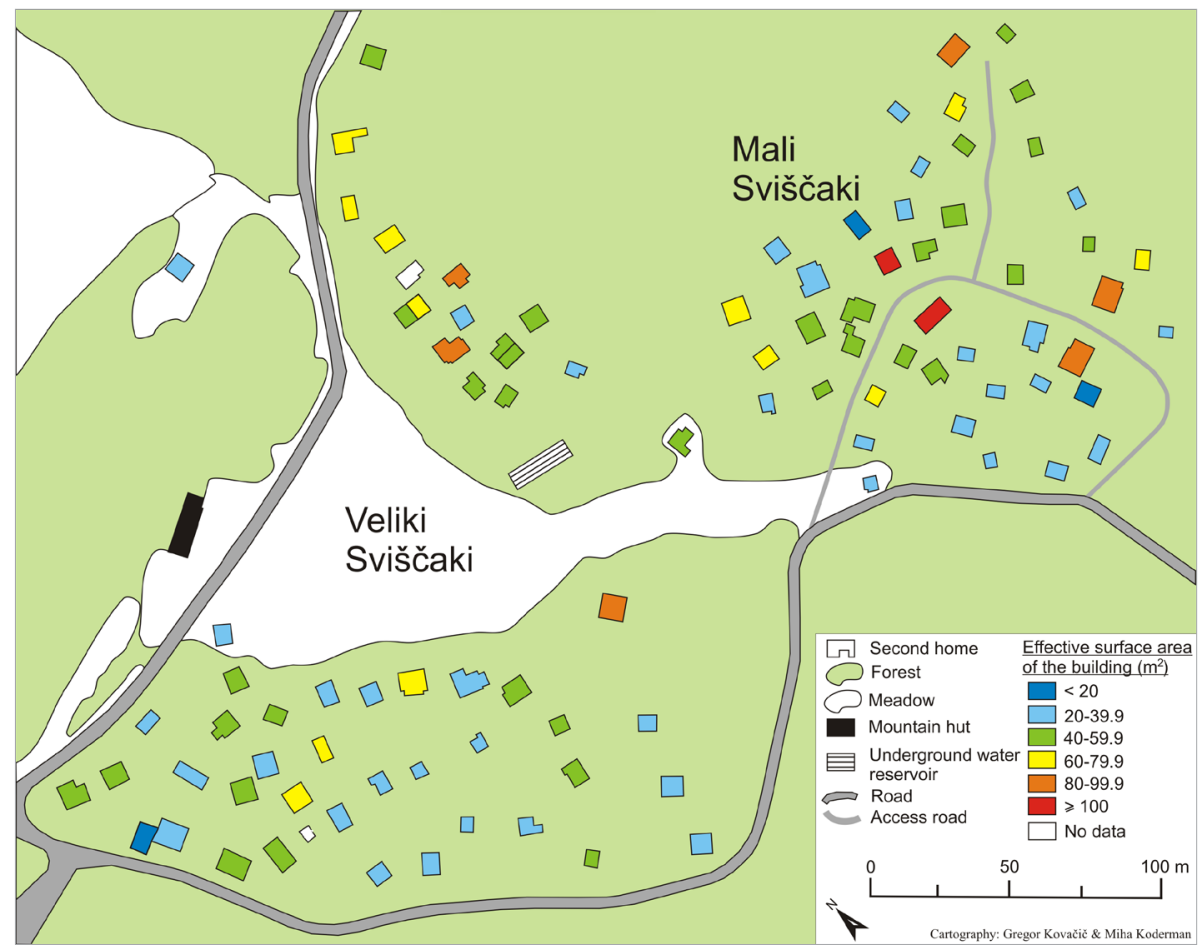

Fig. 6 The size of the holiday dwellings in Sviščaki in relation to their floor area in 2019 Source: Surveying and Mapping Authority of the Republic of Slovenia, 2019 
three stories. Most buildings thus have a much larger living area in reality, as the floor plan represents only the area which is primarily intended as living space (the cellar and the attic usually do not count as living space in this sense). Additional reasons for the large differences between the buildings' actual floor area and documented floor area could stem from real-estate speculation-in 2006 and 2007, the Surveying and Mapping Authority of the Republic of Slovenia carried out an inventory of real estate as a starting point for preparing the Real Estate Registry and the Law on Real Property Tax. By stating a smaller area, some owners of the holiday houses might be attempting to avoid paying higher real estate taxes. Although the aforementioned Law has not yet entered into force, as the Constitutional Court of Slovenia stopped it in 2014, it is expected to enter into force in the near future.

\section{Tourism development plans for the wider area of Sviščaki}

The development of the whole tourism-recreational area Sviščaki, which includes the holiday settlement, is outlined by the OPPN Sviščaki, which entered into force on September $26^{\text {th }}, 2019$ and was officially published in the Official Gazette of the Republic of Slovenia on October $18^{\text {th }}, 2019$ (Development Center Planiranje, 2018a; 2018b; Romih et al., 2018; Official Gazette of the Republic of Slovenia 62, 2019). The area of planning in the OPPN Sviščaki encompasses two units of spatial planning, namely: SV o1, which is designated as a special area for tourist premises, intended for hotels, bungalows, and other facilities needed for accommodation and the general tourism supply, the surface area of which is approximately 14.98 hectares; and SV 02, conceived as an area of green space, intended for recreation and relaxation, as well as sports, the surface area of which is around 29.88 hectares (Romih et al., 2018; Fig. 7).

Crucial spatial plans to be implemented in the area of SV 01 are:

- the elimination and construction of a new mountain hut or the renovation of the existing one, the construction of a hotel with outbuildings (two interconnected buildings), and four bungalows;

- the construction of eleven new holiday houses as well as the renovation and remodelling (reconstruction) of existing ones;

- the construction of a restaurant and sanitary facility as well as sport areas; 
- $\quad$ the construction of a multi-purpose sport and recreation facility with a swimming pool, which would serve as a natural ice rink in the winter;

- $\quad$ arranging the existing multi-purpose grass pitch for ball games and a toboggan run, a children's playground, a bocce court, and a picnic and camping area;

- the restoration, rehabilitation, and improvement of the existing network of access roads, as well as cycling and pedestrian paths;

- the creation of a new car park for vehicles (passenger cars, tourist coaches, campers);

- the renovation, rehabilitation, and extension of facilities of economic public infrastructure, consisting of the power grid, telecommunications network, network for the distribution of water, network and facilities for waste water collection and treatment, and network and facilities for differentiated waste collection and disposal (Development Center Planiranje, 2018a; Official Gazette of the Republic of Slovenia 62, 2019).

Spatial planning to be implemented in the area SV o2 are:

- the removal of several existing facilities (the existing economic facilities near ski lifts, the existing ski lifts), and the construction of new ski lifts (ski draglines and chairlifts) near the existing and planned ski runs (4 appliances) with accompanying service buildings;

- the planned gastronomic and other related facilities for the requirements of maintenance and supply of ski runs;

- the renovation, restoration, and improvement of existing ski slopes (1st and 2nd phases);

- the renovation, restoration, and improvement of the network of cross-country skiing tracks (along the route of the existing road to Mašun);

- the creation of fitness trails, an adventure park, and picnic areas;

- the renovation, restoration, and improvement of the network of existing roads, cycling paths, and walking trails (footpaths, themed routes, rest spots, etc.);

- the construction of a new reservoir for collecting precipitation for artificial snow production on the ski runs; and

- the renovation, restoration, and improvement of facilities pertaining to public infrastructure (the same as for SV o1) (Development 


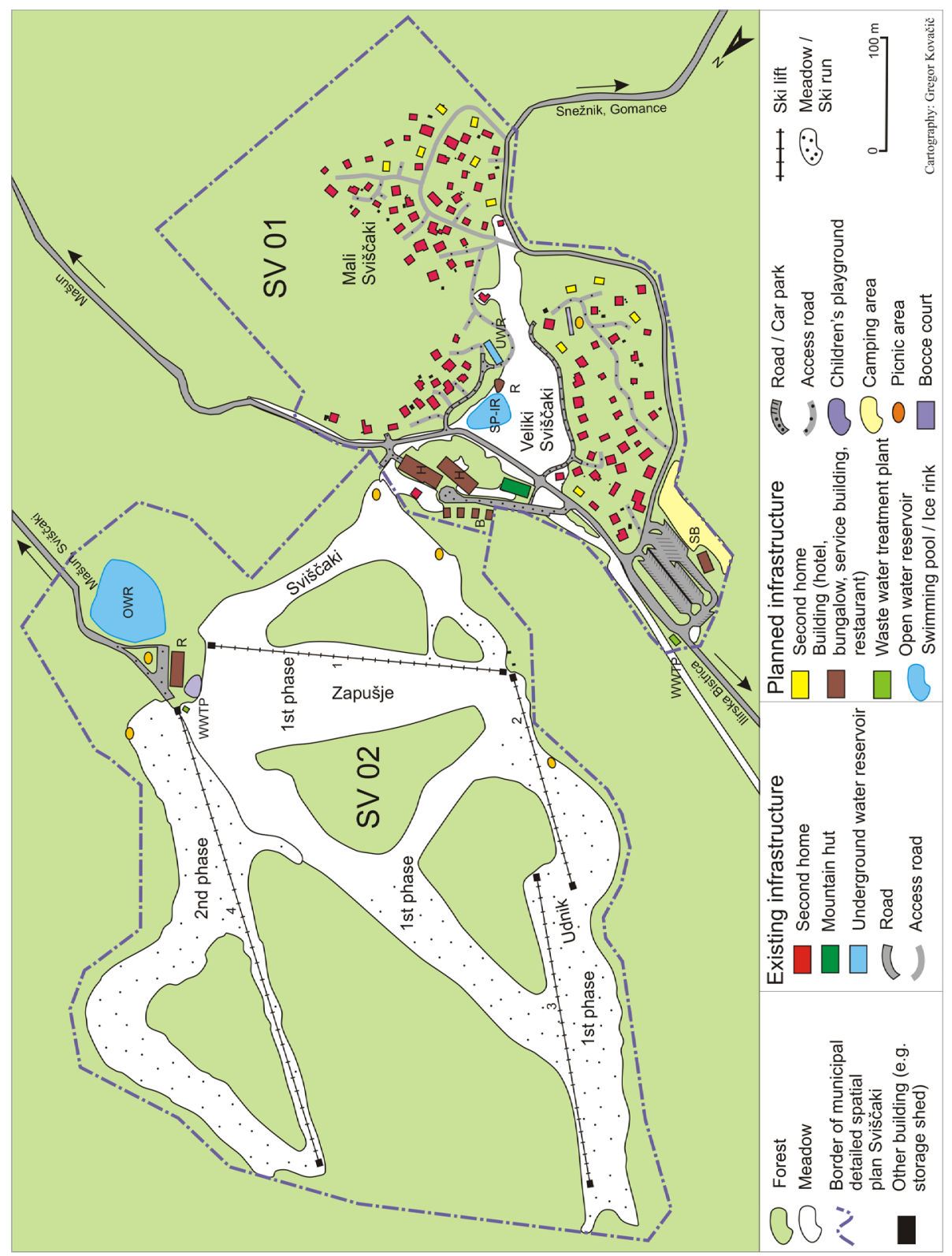

Fig. 7 The area of Sviščaki with existing and planned tourism infrastructure Source: Romih et al. 2018 
Center Planiranje, 2018b; Romih et al., 2018; Official Gazette of the Republic of Slovenia 62, 2019).

In many aspects, the plan for developing the tourism and recreational area of Sviščaki seems very ambitious and in some regards inconsistent with the natural conditions offered by the area of Sviščaki from the perspective of tourism. Some spatial planning authorities have already pointed this out, in regard to the guidelines of the draft by the OPPN Sviščaki. The spatial plan, among other things, envisions the renovation and even expansion of skiing areas, with the restoration of skiing tourism. Ski slopes are envisioned to be upgraded in two stages.

The first stage would encompass the renovation, restoration, and improvement of the existing ski slopes Sviščaki, Zapušje, and Udnik, along ski lifts 1, 2, and 3, covering approximately 9 hectares, while in the second stage, a new ski run would be constructed near ski lift 4, covering an area of approximately 4 hectares (Romih et al., 2018; Official Gazette of the Republic of Slovenia 62, 2019). These plans seem to be unattractive for investors, due to the relatively low altitude of Sviščaki (and lack of sufficient natural snow) and the absence of surface water for artificial snowmaking, which would ensure a longer skiing season-meaning that the infrastructure for artificial generation of snow would have to be constructed from scratch.

Plans for building totally new tourism infrastructure (extension or construction of a new mountain hut, hotel, hotel annex, bungalows, new restaurant buildings, an adventure park, a swimming pool/skating rink, etc.) also relate at least partly to winter forms of outdoor tourism and, to an even greater extent, to summer tourism. However, it is questionable whether these investments will materialise in the future. Implementation appears more realistic for some of the planned tourist infrastructure, like the construction of new holiday houses, arranging of picnic areas, car parks, a camping area, and the corresponding economic facilities, the theme park, urban equipment (elements for sitting, lights, orientation signboards, and information signs), etc.

The OPPN Sviščaki (Official Gazette of the Republic of Slovenia 62, 2019) should usher in many positive changes. Of major importance are the plans for integrated development of the area on the basis of the proper economic public infrastructure, and the conditions and guidelines for architectural and landscape design in connection to the external furnishing of buildings which prescribes the use of natural stone, concrete, classical plas- 
ter, and wood, while also requiring that façades must be in natural hues of stone and wood for all new construction and future renovations (Romih et al., 2018). This measure will significantly improve the general appearance of the second home settlement. The earliest possible adoption of the document is also welcomed by the owners of the holiday dwellings in Sviščaki, as this will finally allow them to regularise the status of land which their holiday houses stand on, as currently not one of the plots with a building has an official number. The owners would like to purchase the land on which their houses are located, though they are also willing to enter into a long-term lease agreements with the Municipality of Ilirska Bistrica (Ferko, 2013). Soon, every holiday house will stand on its own land parcel.

The OPPN Sviščaki envisages the maintenance of the potable water supply in its existing form, using existing rainwater capturing systems (Romih et al., 2018, 35), which is appropriate considering the amount precipitation in the area, and the existing infrastructure and technical knowhow regarding rain/snow water collection. Construction of a regional water supply system from water sources at a lower altitude is not cost-effective at present. We estimate, however, that the drinking water supply is not a limiting factor for future tourism development in Sviščaki.

A major new gain for the holiday settlement will be the construction of a sewage network and a central underground water treatment plant with the capacity of 500 population equivalent (PE), to which all the existing and planned facilities in Sviščaki will have to be connected. This implies that the septic tanks in the holiday houses will lose their function. The motorhome area in the central car park will also be connected to the sewage system (Romih et al., 2018, 35). A separate system is planned for the disposal of run-off rain water. The drainage water from the buildings' roofs would be retained and used for watering plants or as drinking water; from the surfaces of larger tourist establishments (hotel, bungalows, the large mountain hut) and the hard-paved surfaces surrounding them as well as car parks, water would be released into the reservoir planned for snow production (Romih et al., 2018, 36). It is not known how the disposal of run-off rain water would be carried out in the event that the construction of a reservoir for snow production (for the ski runs) does not take place. The planned improvements also include a small water treatment plant with the capacity of $50 \mathrm{PE}$, intended for the restaurant envisioned next to the ski run, which could, however, also be replaced with a watertight septic tank (Romih et al., 2018, 35; Official Gazette of the Republic of Slovenia 62, 2019). 
The OPPN Sviščaki (Official Gazette of the Republic of Slovenia 62, 2019) also envisions an arrangement of a central car park in the area of the current car park in the western part of Sviščaki, with approximately 90 parking spaces for cars, 10 spaces for campers, and up to 5 spaces for buses. The plan also includes 25 parking spaces in the area of the mountain hut, the planned bungalows, and the hotel. Parking spaces for cars near holiday houses will be arranged as part of functional land as garages or outside car parks, i.e. one to two parking spaces per building (Romih et al., 2018).

The main energy product for heating buildings is still wood, according to the OPPN Sviščaki (Official Gazette of the Republic of Slovenia 62, 2019), which can be complemented with fuel oil and electricity. It is possible to arrange shared heating for multiple buildings, but this is not required. The planned power supply does not foresee any major investments, however, the plan allows for the installation of photovoltaic cells on the exposed parts of roofs and façades, and some elements of urban equipment. Routes for the electronic communication network are also envisaged (Romih et al., 2018).

The OPPN Sviščaki (Official Gazette of the Republic of Slovenia 62, 2019) also envisions an improved management of waste collection and disposal; waste will be collected by each establishment separately, and deposited at technically-suitable fixed spots where containers for differentiated waste collection will be placed (Romih et al., 2018, 36). As we have already mentioned above, the current state of waste collection in Sviščaki is insufficient in terms of environmental standards, which is why the proposed solution will significantly contribute to the better image of the area, as long as there is consistent compliance with the rules and required standards. In line with the OPPN Sviščaki, containers will have to be airtight so that the smell of waste will not spread, and they will be enclosed with a fence so that animals will not be able to access them. The same goes for freestanding waste bins (Uljan, 2018, 4), though we have certain doubts whether it makes sense to install these, instead of just relying on a simple rule requiring guests to either take their waste back to the valley, which would apply to day-trippers visitors, or to dispose of it in designated areas.

\section{Conclusion}

The second homes in the area of Sviščaki, which experienced the most intense level of development in the 1980s, caused significant changes in the natural environment of Snežnik Plateau over the course of several dec- 
ades. The buildings constructed in the sensitive karst landscape, where we find numerous natural treasures and ecologically significant areas that are protected as part of Natura 2000, are problematic in a number of aspects, among which we can highlight the uncontrolled disposal and treatment of waste water and the failure to comply with the traditional architectural patterns.

Although the adoption of The Ordinance on the Construction Plan for the Area of Sviščaki (1967) and The Rules on the Implementation of the Construction Plan for the Area of Sviščaki (1967) brought crucial spatial planning documentation to the area, the regulatory prescriptions were defined too broadly to prevent architectural-physiognomic imbalances and the unbridled construction of new facilities. On the other hand, we can only imagine the chaos that might have ensued without the aforementioned ordinances, in terms of the development of the second home settlement.

By adopting the OPPN Sviščaki (Official Gazette of the Republic of Slovenia 62, 2019), the Municipality of Ilirska Bistrica intends to offer this area new opportunities for development. The spatial plan also discusses an increase in the number of holiday dwellings in places where they are currently already relatively concentrated. We believe that it would be wiser to approach the renovation of the existing buildings that are in the process of decay; and considering all the large-scale development plans, we need to be, above all, conscious of the significant role of this unique natural area, which could suffer irreparable damage in the event of reckless and unsustainable interventions.

\section{References}

Brižan, M., 2016: Razvojne možnosti turizma na Sviščakih z okolico z vidika okoljskih učinkov, Graduation Thesis, Univerza na Primorskem, Fakulteta za humanistične študije, Koper.

Cigale, D., 2009: Turizem in rekreacija kot dejavnika okoljskih obremenitev, in: Okoljski učinki prometa in turizma $v$ Sloveniji (eds. Špes, M., Ogrin, D.), Znanstvena založba Filozofske fakultete Univerze v Ljubljani, Ljubljana, 86-105.

Čeligoj, V., 20ooa: Planinstvo med obema vojnama, in: Knjiga o Snežniku (ed. Čeligoj, V.), Planinsko društvo Snežnik, Ilirska Bistrica, 64-68.

Čeligoj, V., 20oob: Planinstvo, posvečeno Snežniku, in: Knjiga o Snežniku (ed. Čeligoj, V.), Planinsko društvo Snežnik, Ilirska Bistrica, 56-60. 
Čeligoj, V., 20ooc: Prvo desetletje po svobodi, in: Knjiga o Snežniku (ed. Čeligoj, V.), Planinsko društvo Snežnik, Ilirska Bistrica, 69-70.

Čeligoj, V., 2oood: Društvo zgradi planinski dom na Sviščakih, in: Knjiga o Snežniku (ed. Čeligoj, V.), Planinsko društvo Snežnik, Ilirska Bistrica, 78-80.

Čeligoj, V., 20ooe: Leta prvih gradbenih podvigov, in: Knjiga o Snežniku (ed. Čeligoj, V.), Planinsko društvo Snežnik, Ilirska Bistrica, 73-76.

Čeligoj, V., 20oof: Koča na Snežniku dobi današnji izgled, in: Knjiga o Snežniku (ed. Čeligoj, V.), Planinsko društvo Snežnik, Ilirska Bistrica, 91-94.

Gams, I., 1983: Geografske značilnosti Slovenije, Mladinska knjiga, Ljubljana.

Gams, I., 1986: Pokrajinska ekologija, Filozofska fakulteta, Ljubljana.

Gams, I., Kladnik D., Orožen Adamič, M., 1995: Naravnogeografske regije Slovenije, in: Krajevni leksikon Slovenije (ed. Perko, D.), DZS, Ljubljana.

Gosar, A., 1987: Geografski vidik razvoja počitniških bivališč na Notranjskem in Primorskem, in: Notranjska: zbornik 14. zborovanja slovenskih geografov, Postojna (ed. Habič, P.), Zveza geografskih društev Slovenije, Postojna, 251-264.

Klemenčič, V., 1959: Pokrajina med Snežnikom in Slavnikom. Založba ZRC SAZU, Ljubljana.

Koderman, M., Salmič, S., 2013: Prebivati ob “jezeru bliz’ Triglava”: Prostorska analiza počitniških bivališč v občini Bohinj, in: Gorenjska v obdobju glokalizacije (eds. Mrak, I. et al.), Znanstvena založba Filozofske fakultete Univerze v Ljubljani, Ljubljana, 111-125.

Koderman, M., 2014: Spatial Analysis of Second Homes in the Municipality of Piran, Academica turistica 7 (2), 179-191.

Koderman, M., 2017: Second Homes in Protected Areas of Slovenia - The Case of the Triglav National Park, in: Tourism in Protected Areas of Nature in Serbia and Slovenia (eds. Filipović, D. et al.), University of Belgrade, Faculty of Geography, Belgrade, 87-100.

Koderman, M., Pavlič, M., 2019: Second homes in the Slovenian Alps with special emphasis on the municipality of Bovec, Hrvatski geografski glasnik 81 (1), 61-81, DOI: 10.21861/HGG.2019.81.01.03.

Komac, B., Zorn, M., Kušar, D., 2012: New possibilities for asses sing the damage caused by natural disasters in Slovenia - The case of the Real Estate Record, Geografski vestnik 84 (1), 113-127. 
Kovačič, G., 2001: Pokrajinska ogroženost in ukrepi za zaščito kraškega izvira Bistrica. Annales: anali za istrske in mediteranske študije - Series Historia Naturalis 11 (1), 93-104.

Kovačič, G., 2003: Kraški izviri Bistrice (JZ Slovenija), Annales: anali za istrske in mediteranske študije - Series Historia Naturalis 13 (1), 111-120.

Lovrenčak, F., 1976: Zgornja gozdna meja v Kamniških Alpah v geografski luči (v primerjavi s Snežnikom), Založba ZRC SAZU, Ljubljana.

Melik, A., 1960: Slovensko primorje. Slovenija: geografski opis 2, Slovenska matica, Ljubljana.

Perko, D., Orožen Adamič, M., 1998 (eds.): Slovenija, pokrajine in ljudje, Mladinska knjiga, Ljubljana.

Salmič, S., Koderman, M., 2013: Prostorska analiza počitniških bivališč v Občini Kranjska Gora, Geografski vestnik 85 (1), 9-24.

Senegačnik, J., 2012: Slovenija in njene pokrajine, Modrijan založba, Ljubljana.

Wraber, T., 200o: Koča na Kranjskem Snežniku, in: Knjiga o Snežniku (ed. Čeligoj, V.), Planinsko društvo Snežnik, Ilirska Bistrica.

Zupančič, J., 1998: Javorniki in Snežnik, in: Slovenija: pokrajina in ljudje (eds. Perko, D., Orožen Adamič, M.), Mladinska knjiga, Ljubljana, 334-341.

\section{Sources}

Alpine Association of Slovenia, 2019a: Planinski dom na Sviščakih (1242 m), https://www.pzs.si/koce.php?pid=171 (09. 08. 2019)

Alpine Association of Slovenia, 2019b: Koča Draga Karolina na Velikem Snežniku (179o m), https://www.pzs.si/koce.php?pid=168 (o9. 08. 2019)

Čeligoj, V., 2019a: Značka planinske koče na Klanski polici, Snežnik 1935, Portal kamra, digitalizirana kulturna dediščina slovenskih pokrajin, https:// www.kamra.si/album-slovenije/item/znacka-planinske-koce-na-klanski-polici-sneznik-1935.html (o9. o8. 2019)

Čeligoj, V., 2019b: Smučarski vrvež na Klanski polici, 1933, Portal kamra, digitalizirana kulturna dediščina slovenskih pokrajin, https://www.kamra.si/ album-slovenije/item/smucarski-vrvez-na-klanski-polici-1933.html (o9. o8. 2019)

Čeligoj, V., 2019c: Reški smučarji preplavili snežniška pobočja, 1930, Portal kamra, digitalizirana kulturna dediščina slovenskih pokrajin, https:// www.kamra.si/album-slovenije/item/reski-smucarji-preplavili-snezniska-pobocja-1930.html (o9. 08. 2019) 
Čeligoj, V., 2019d: Smučarji na Mašunu, 1932, Portal kamra, digitalizirana kulturna dediščina slovenskih pokrajin, https://www.kamra.si/album-slovenije/item/smucarji-na-masunu-1932.html (o9. o8. 2019)

Čeligoj, V., 2019e: Smučarji na Mašunu, 1932, Portal kamra, digitalizirana kulturna dediščina slovenskih pokrajin, https://www.kamra.si/album-slovenije/item/smucarski-skoki-iz-hrvaske-v-slovenijo-193o.html (09. 08. 2019)

Čošić, J., 2019: Oskrbnica Planinske doma na Sviščakih, Oral source, (o1. o8. 2019)

Development Center Planiranje, 2018a: Občinski podrobni prostorski načrt za turistično središče Sviščaki, dopolnjen osnutek - povzetek za javnost, Razvojni center planiranje, Celje, https://www.ilirska-bistrica.si/mma//2018022708493082/?m= (o8. 08. 2019)

Development Center Planiranje, 2018b: Odlok o občinskem podrobnem prostorskem načrtu za turistično središče Sviščaki, dopolnjen osnutek, Razvojni center planiranje, Celje, https://www.ilirska-bistrica.si/mma//2018022612314973/?m= (o8. 08. 2019)

Ferko, L., 2013: Z načrtom bi “spontano” naselje postalo urejeno, Primorske novice, http://www.primorske.si/Primorska/Srednja-Primorska/Znacrtom-bi--spontano--naselje-postalo-urejeno.aspx (01. o8. 2019)

Francek Ivović, S., 2015: Propada tudi nekoč zelo priljubljeno smučišče Sviščaki, Prvi dnevnik, RTV Slovenija, https://4d.rtvslo.si/arhiv/prvi-dnevnik/174315106 (19. 01. 2015)

Francek Ivović, S., 2017: Turistična oživitev na Sviščakih, Prvi dnevnik, RTV Slovenija, https://4d.rtvslo.si/arhiv/prvi-dnevnik/174510802 (27. 12. 2017)

Francek Ivović, S., 2018a: Na Sviščakih bi odprli razpršeni hotel, Slovenska kronika, RTV Slovenija, https://4d.rtvslo.si/arhiv/slovenska-kroni$\mathrm{ka} / 174537381$ (07. 05. 2018)

Francek Ivović, S., 2018b: Koča na Sviščakih potrebuje prenovo, Poročila, RTV Slovenija, https://4d.rtvslo.si/arhiv/porocila/174585820 (30. 12. 2018)

Jaksetič, D., 2009: Na Snežniku nova sončna elektrarna: več elektrike za planinsko zavetišče, Delo, 4. 7. 2009.

Kalc Furlanč, L. 2015: Bo smučanje na Sviščakih le še oddaljen spomin?, Primorske novice, http://www.primorske.si/Novice/Srednja/-Bosmucanje-na-Sviscakih-le-se-oddaljen-spomin (o4. 02. 2015)

Kirn Vodopivec, K., 2019a: V obnovljen dom na Sviščakih bo kmalu vodila asfaltna cesta, Primorske novice, 15. 7. 2019. 
Kirn Vodopivec, K., 2019b: Po prenovi na Sviščakih tudi prenočišča, Primorske. si., https://www.primorske.si/primorska/srednja-primorska/po-prenovi-na-sviscakih-tudi-prenocisca (01. 08. 2019)

Mulec, S., 2018: Na Sviščakih vzpostavljajo razpršeni hotel, Notranjskoprimorske novice. https://notranjskoprimorske.si/2018/04/na-sviscakih-vzpostavljajo-razprseni-hotel/ (18. 08. 2019)

Municipality of Ilirska Bistrica, 2019: Municipality of Ilirska Bistrica, Oddelek za družbene dejavnosti.

Mountain Hut Sviščaki, 2019: http://www.sviscaki.com/index.php/o-nas (o9. 08. 2019)

Official Gazette of the Republic of Slovenia 62, 2019: Odlok o Občinskem podrobnem prostorskem načrtu za turistično središče Sviščaki.

Romih, R., Toman, T., Teržan, N., Geršak Podbreznik, A., Povalej, I., Šetina, M., Čosič, S., 2018: Občinski podrobni prostorski načrt za turistično središče Sviščaki, dopolnjen osnutek, https://www.ilirska-bistrica.si/ $\mathrm{mma} /-/ 2018022612312966 / ? \mathrm{~m}=(08.08 .2019)$

Slovenian Forest Service, območna enota Postojna, 2013: Gozdnogospodarski načrt gozdnogospodarske enote Okroglina (2013-2022), http://prostor.zgs. gov.si/pregledovalnik/ (10. 08. 2019)

Ski Club Snežnik, 2019a: Kako smo nastali, http://www.sk-sneznik.com/?p=58 (12. 08. 2019)

Ski Club Snežnik, 2019b: Glavne aktivnosti smučarskega kluba, http://www. sk-sneznik.com/?p=59 (12. o8. 2019)

Ski Club Snežnik, 2019c: Prva vlečnica na Sviščakih, http://www.sk-sneznik. $\mathrm{com} /$ ? $\mathrm{p}=62$ (12. 08. 2019)

Ski Club Snežnik, 2019d: Pokal Snežnika in ostala tekmovanja, http://www. sk-sneznik.com/?p=61 (12. o8. 2019)

Statistical Office of the Republic of Slovenia, 2019: Prebivalstvo po velikih in petletnih starostnih skupinah in spolu, naselja, Slovenija, letno, https://pxweb.stat.si/SiStatDb/pxweb/sl/10_Dem_soc/10_Dem_soc__05_prebivalstvo__10_stevilo_preb__25_05C50_prebivalstvo_naselja/o5C5002S.px/ 8 (07. 08. 2019)

Surveying and Mapping Authority of the Republic of Slovenia, 2019: Kataster stavb.

Tavčar, B., 2016: Manj kot pet odstotkov greznic je ustreznih, Delo, http://www. delo.si/novice/okolje/manj-kot-pet-odstotkov-greznic-je-ustreznih.html. 
The Ordinance of the Development Plan for the Area of Sviščaki (Odlok o zazidalnem načrtu za območje Sviščakov), 1967: Uradne objave Primorskih novic, št. 18, Koper.

The Rules on the Implementation of the Development Plan for the Area of Sviščaki (Pravilnik o izvajanju zazidalnega načrta za območje Sviščakov), 1967, Občina Ilirska Bistrica, Ilirska Bistrica, 1967.

Uljan, A., 2018: Zapisnik iz javne obravnave dopolnjenega osnutka OPPN Sviščaki in okoljskega poročila, Občina Ilirska Bistrica, https://www.ilirska-bistrica.si/obcinska-uprava/urejanje-prosto$\mathrm{ra} / 2017102508431955 / 2018052814022586$ (25. 08. 2019)

UNESCO, 2019: World Heritage List, Ancient and Primeval Beech Forests of the Carpathians and Other Regions of Europe, https://whc.unesco.org/en/ list/1133/documents/ (10. 10. 2019)

Vesenjak, P., 2010: Investicijski program z idejno zasnovo za investiranje v turistično infrastrukturo Sviščaki, Hosting d.o.o., Ptuj. 